\title{
The Impact of School Library on Development of Entrepreneurial Skills in Students
}

\author{
Angelina Bijelic
}

University of Zagreb

Mihaela Banek-Zorica, Ph.D. mbanek@ffzg.hr

University of Zagreb

Keywords: entrepreneurial skills, learning for entrepreneurship, school libraries, student activities

\begin{abstract}
Entrepreneurial skills are among the most important elements of development of each individual, both on a business plan and in any other segment of life. To be an innovative, creative and active member of society and community, prepared to constantly develop existing and create new knowledge and skills, are the fundamental determinants of overall social and economic progress. The aim of this paper is to highlight the importance of the impact of school library on development of entrepreneurial skills of each individual, which should be encouraged through education from the earliest age in order for the young person to develop a thinking ability that leads to success, inventive solutions to any life problem, worked-out planning and organization strategies, real risk acceptance and responsible behavior towards oneself and society before starting an independent life.
\end{abstract}

\section{Introduction}

Entrepreneurship is an essential economic and social phenomenon receiving insufficient awareness and space in all fields of human activity during life. Development of the human mind and social progress have produced a striving for a higher quality of life. High quality of life demands an active lifelong learning process, interests in acquiring new skills in life and systematical search for new possibilities and monitoring of up-to-date content of interest. Many people have excellent ideas, however, not everyone is able to put them into practice. Since entrepreneurship is the ability of an individual to put ideas into practice, not being able to do so means the lack of entrepreneurial skills.

The concept of entrepreneurship has existed as long as the system we call human society. The concept of entrepreneurship has been approached differently and used in different contexts, but not systematically and comprehensive enough. For decades, entrepreneurship has been viewed as an entirely economical concept, tied to growth and development of companies, smaller or larger businesses in which entrepreneurship is based on the economic theory and experiences of economical services. Entrepreneurs 
have been viewed as capitalists and investors, and entrepreneurship as a specific economical trait of an individual, most often employer or an institution. The above statement can be confirmed by the broadest definition of entrepreneurship found on Croatian Wikipedia (n.d.): "Entrepreneurship is an economic activity of an individual or multiple partners that requires financial investment and accepting risks and uncertainty to enter a business venture in order to make a profit. It is a way of economic activity in which the entrepreneur decides what, how and for whom to create and accomplish on the market at his own expense and risk in order to make a profit." Over time, the importance of entrepreneurship for each individual has been understood and the concept has become an essential part of social domain. Understanding of the concept of entrepreneurship has evolved with social progress.

Social progress and awareness of the whole spectrum of possibilities that entrepreneurship offers for each individual's development started changes in perceptions and hence the explanations related to the concept of entrepreneurship. This can be confirmed by National curriculum of the cross-curricular theme of entrepreneurship, a document in which entrepreneurship is defined as a value that assumes activating personal potentials in a creative, constructive, responsible and innovative way in order to adapt to the changing circumstances in different areas of life and different social roles. Sense of initiative and entrepreneurship is one of the key competences of European Reference Framework of Key Competences for Lifelong Learning and is necessary for any citizen's ability of (self) employment and personal development in a society of knowledge (Ministry of Science and Education of the Republic of Croatia, December 2017).

The importance of entrepreneurship is illustrated by the introduction of entrepreneurship as one of the eight key competences of students into the National and framework curriculum in 2010 and as a cross-curricular theme in the proposal of National curriculum after public hearing. In order to understand entrepreneurial skills it is necessary first to understand the qualities of entrepreneurship and what it really means to be an entrepreneur. "The attributes of entrepreneurship that most of the students possess are openness to changes and new experiences, preparedness for cooperation and agreement with their peers" (Štalo, 2012). The cited statement reveals attributes that are closely related and condition each other; they are brought together by two central concepts: change and cooperation. The causality of the mentioned entrepreneurial attributes can be explained by the following process: each individual strives for a higher quality of life, which depends on new experiences, and these depend on the previous openness to change. Apart from the openness to one's own progress and new experiences, the attributes of cooperation and agreement are extremely important for each individual to become socially sensible, active and a responsible member of his community.

There are many entrepreneurial skills, but for the purpose of this paper, we'll highlight just a few. While planning certain activities which aim to build entrepreneurial skills in students, it's necessary to work out the functional tasks well during preparation since "the specific emphasis is on functional tasks that build different entrepreneurial skills capabilities in students: initiative, independence, accepting risks, innovativeness, creative problem-solving, self-confidence, persistence, reporting skills, cooperation and flexibility in a team and others." (Lovrenčić and Vrančić, 2019)

When entrepreneurial skills are considered, the focus is at preparing the students for independent, productive and successful life and laying the foundation for upgrading existing acquired skills with new ones, which will be further developed by students after primary school and high school education at higher educational institutions or in business and private surroundings. "...developing entrepreneurial way of thinking and acting in everyday life and work, learning to work and development of qualities of

International Association of School Librarianship

https://iasl-online.org 
entrepreneurial person (responsibility, independence, industriousness, initiative, creativity, decision-making capability, self-confidence, decisiveness, accepting reasonable risks and risk management, mobility, flexibility, etc.)" (Ministry of Science and Education of the Republic of Croatia, December 2017)

\section{The Role of the School Library in Curriculum}

For a long time, school libraries in Croatia were considered a passive space at school, where students went to borrow a book or to be if there were no classes. Through the years things have gradually changed. School librarians were actively participating in the process that aimed to enable the proper and trustworthy reputation of school libraries, which assumed the awareness of the great value and importance of school libraries as a central information, educational, cultural and social center of every school. This negative reputation, created during decades, is not easy to change, so school librarians have demanding tasks and certain challenges in front of them. First steps happened when school library programs started to be integrated into the school curriculum, although a majority of the activities were oriented towards reading or media culture while connection with other subjects was usually neglected.

Over time, awareness of possibilities and roles of school libraries gradually grew, society and technology developed and the importance of information centers became more acknowledged; this caused changes in definitions of school libraries, approach to education and training of school librarians, and the need for a suitable media space that would successfully follow and satisfy the needs of modern individuals. "School library is a physical and digital space in a school, intended for learning, where reading, research, thinking, imagination and creativity are of key importance for students on their path from information to knowledge and for their personal, cultural and social development. This physical and digital space is known under different names (e.g. school media center, documentation and information center, learning center), but for all such content and services, the most often used name is school library." (Schultz-Jones and Oberg, 2015)

Modern society is a society that strives for information and knowledge. A vast amount of information is at disposal to every member of modern society, and more of them are useless than useful if the individual is not computer-literate. While in contact with different media, one must understand the type of media being accessed, have a clearly defined goal about which information is sought and be aware of the need to filter the available information to avoid unnecessary waste of time coming from drawing attention to useless content. School library plays a major role in the mentioned segments, since as an information center of an educational institution it is concerned with the computer literacy of its users and all other individuals. "School library gives information and knowledge essential for successful functioning in modern society which is increasingly being based on information and knowledge. School library helps students acquire lifelong learning skills, develops their imagination and hence helps them to become responsible citizens." (Sætre and Willars, 2002)

For a longer period of years an educational model has been sought that would enable a school for life, learning about learning, knowledge about knowledge and an excellent basis to improve self-awareness and self-development. "School library supports education in further expanding student's knowledge, using different methods and means for students to express themselves aiming for complete development of each student, so that he/she can fully rely on himself/herself. Accordingly, educational content corresponds to individual needs and development of a student." (Kovačević, Lasić-Lazić and Lovrinčević, 2004) The above statement leads to the conclusion that school libraries have an essential role in development and future success of each student, and consequently the whole society.

International Association of School Librarianship

https://iasl-online.org 
The reputation, role and perception of school library (and hence of the whole school) depends on the qualities of school librarian as a teacher, collaborator and professional. In order for the school library to have a dignified reputation in an institution, a qualified, capable and entrepreneurial school librarian is needed, whose reputation is affirmed by the following activities: creating a positive and friendly learning environment, helping users become computer-literate, promoting research-based learning, revealing their own possibilities to students, developing self-confidence and independence in students, giving advice and encouraging students to work, monitoring and helping, self-education and training, constantly searching for new methods, cooperating with the principal and other employees within and outside the institution, cooperatively supporting the curriculum, friendly and warm approach to all visitors of the library, promoting the value of school library, media-related education and fulfilling the expectations of all users. (Kovačević, Lasić-Lazić and Lovrinčević, 2004)

A school librarian has a great responsibility on multiple levels: educational, cultural and artistic, social, status and professional. On an educational level, a school librarian has to participate in the teaching process, build upon, develop, improve and support the teaching process directly or indirectly. In cultural and artistic domain, all manifestations, exhibits, promotions, public shows, matinées, concerts and other events should be planned ahead and organized by a school librarian. On social and status level, a school librarian should shrewdly plan his/her status, and through this the status of school library in an institutional community and make social impact on institutional level and outside of it. Professional level of school librarian responsibility is tied to information sciences, constant education and professional training in order to completely fulfill the expectations and needs of users.

\section{Developing Entrepreneurial Skills in School Library}

School librarian has a very important role in devising different meaningful activities and workshops aiming to build different skills in students, offering different possibilities, creating a sound foundation for self-growth and development and for lifelong learning which is an essential segment in the progress of the whole society.

Activities and workshops need to contain carefully planned tasks organized by a well-prepared expert that is constantly being trained, attends different workshops and deepens own knowledge and skills from different sources. School librarian in fact has a large number of tasks and responsibilities that come before any plans and organization of participation in direct or indirect educational process.

Every activity can have one or more goals, however, when planning any activity, one of the main goals should be promotion of school library. Goals can be monitored through outcomes, and success in reaching the mentioned goals can be found out by evaluation after each activity. After each activity is completed, the school library should have several visitors more. More visitors mean increased possibility of interest in information offered by school library via different media, but also a higher awareness of the inseparability of school libraries from the education system and any kind of learning.

"Libraries that wish to offer effective and meaningful programs need to strive to include young people in all the steps of program making. It is recommended to include young people in decision making, planning and implementation of programs intended for them, which is the best way to add to their positive development." (Barbaric, 2009) This quote introduces the idea that can greatly improve the success of activities, i.e. inclusion of students' ideas, interests, desirable subjects and types of tasks they would like to work on. While planning an activity, it is desirable to devise tasks that most students can participate in and demonstrate their skills. 
The possibilities for creating new or choosing existing activities for influencing development of entrepreneurial skills in students are great and encompass more than one entrepreneurial skill within a single task.

For example, if the goal of a certain activity is to influence the development of creativity in students, and the plan is to work with a group of students divided into smaller groups, apart from creativity, the entrepreneurial skills of cooperation and agreement with other group members are being built, while independence, decision-making, determination, flexibility, responsibility or diligence can be developed at the same time.

\section{Scenario for the Entrepreneurial Skills Development Workshop: Paper Airplanes}

This activity is intended for work in groups and is competitive. It includes practical work and several working materials. Students need to be divided into several groups (every group should have at least 3 members, and overall group size should be the size of one class), they should be asked to assign roles within their groups and make a strategy (group leader, record keeper, executioner), task should be explained and basic information about duration and following activities should be provided. Working materials should be provided after that. Students can assign roles according to each phase of the task, but can also help one another.

Task: Your task is to make airplanes from 6 A4 papers at your disposal. You have 2 minutes for agreement and strategy, 10 minutes for making airplanes from your material and 5 minutes for throwing airplanes inside the designated space in the school library or classroom. The goal of this task is to throw as many airplanes as possible inside the designated space in the school library or classroom.

This task can help build the following entrepreneurial skills:

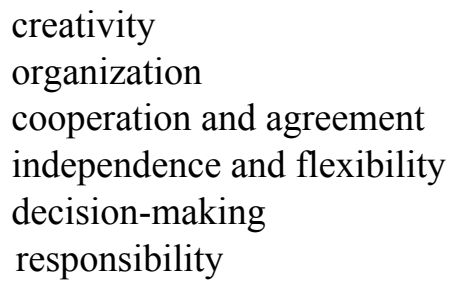

Since creativity is a mental process that includes creating new ideas, concepts, problem solutions or new links between existing ideas and concepts, this task helps build creativity because students need to think of ways to make as many airplanes as possible that will land into designated space. The organization skill is developed before starting the actual task, since students need to organize within a group, assign roles and determine who does what and in which order. While planning a strategy, students work together to make agreements, exchange ideas, make and accept suggestions and thus build collaboration and agreement. During the making of airplanes, airplanes are being made either by a single person that does it best or by several group members that may each make the whole airplane at the same time or assign different steps among themselves. By making airplanes, students develop independence as well, since each student is focused on his/her own contribution in making of airplanes. Developing flexibility occurs during disagreement with an idea and adapting to the wishes and vision of the group. Decision-making is developed during preparation of strategy and at the moment of throwing airplanes into the designated space in the school library or classroom and accepting responsibilities for the final decisions, regardless of the final outcome.

International Association of School Librarianship

https://iasl-online.org 
Making paper airplanes is an activity that makes students face challenges, quick decision-making and developing strategies, risks, possibility of failure, accepting responsibilities for the activity outcome and assessment of own strategy and planning for improvement. Challenges are reflected in the activity set-up, meaning that it demands making as many airplanes as possible that will fly to a defined distance. There is a possibility that some groups will focus on the amount of the airplanes, regardless of the quality and shape of airplanes suitable for flying to a distance, while another group may focus on maximizing the quality of airplanes in order to make each of them to make it to the defined distance. Also, some students may go for both quality and quantity of airplanes. The challenge is to choose a goal, which is an essential decision in planning a strategy of making airplanes. Participants choosing quantity of airplanes over quality take the risk that none of the airplanes will fly into the designated space, while participants that choose quality over quantity risk that, even if all airplanes fly into the designated space, there may not be enough airplanes for victory. Also, regardless of quality and quantity of the airplanes, there is a possibility that the success will depend mostly on the capability of students to assess the necessary strength, speed, height, and the way of throwing airplanes into designated space. In each case, there is a possibility of failure, and students need to be made aware that this is an essential part of success and entrepreneurship itself. It is important to accept responsibility for failure, after which the strategy is being assessed and plans for improvement are carefully made. Students learn that every failure is a stepping stone to success and an opportunity for development, improvement, learning and acquiring new knowledge and skills.

This simple activity is extremely adaptable to all age groups and workshop types, enables minimal material cost, is very efficient in building above-mentioned entrepreneurial skills and stimulates curiosity in students, as well as interest and motivation for acquiring new knowledge and skills.

The above mentioned example shows that a large number of entrepreneurial skills can be covered by a single activity, which confirms the importance of their implementation. It would be right to assume the great impact of school libraries on building entrepreneurial skills in students if just one planned activity results in success, not just in building entrepreneurial skills, but also in promoting the importance and reputation of school libraries, librarianship and maximizing the number of active users that will use the information from school libraries to develop the need for new knowledge and skills and influence the improvement of the whole society.

\section{Conclusion}

Upon completing their education, students should, according to their formed views, beliefs and attitudes be able to recognize their own interests and skills as well as plan and organize next steps in life accordingly. School library, a part of the educational system and cultural and social life of a student, should devise and enable different activities and services that stimulate building work-related values that jointly make up the entrepreneurial skill system.

Since young people in this digital age are overloaded with vast amount of information, the role of the school library is to choose information and content to offer young people which will be useful for self-development and lifelong learning. Content offered by school libraries will stimulate the open-minded thinking ability, problem-solving creativity, idea originality, planning and organizing idea implementation, cooperation and smart thinking for oneself and community.

The aim of this paper was to highlight the importance and role of school libraries on the development of entrepreneurial skills of students by showing and explaining certain activities that may be offered by school libraries to accomplish this goal.

International Association of School Librarianship

https://iasl-online.org 


\section{REFERENCES}

Barbaric, A. (Ed.) (2009). Smjernice za knjižnične usluge za mladež. Zagreb : Hrvatsko knjižničarsko društvo.

Kovačević, D. Lasić-Lazić, J. Lovrinčević, J. (2004) Školska knjižnica - korak dalje. Zagreb : Faculty of Humanities and Social Sciences, Institute for information studies, Department of Information and Communication Sciences.

Lovrenčić, S. Vrančić, M. (2019) Poduzetničke vještine u osnovnoj školi : razredna nastava - primjer dobre prakse. Učenje za poduzetništvo, Vol 2(2). 211-215.

Ministry of Science and Education of Republic of Croatia. (2017). National curriculum of the cross-curricular theme of entrepreneurship: a proposal after public hearing. [Online]; MZO, December 2017.

https://mzo.gov.hr/UserDocsImages//dokumenti/Obrazovanje/NacionalniKurikulum/Medupredm etneTeme $/ \mathrm{Me} \% \mathrm{C} 4 \% 91$ upredmetna $\% 20$ tema $\% 20$ Poduzetni $\% \mathrm{C} 5 \% \mathrm{~A} 1$ tvo.pdf (accessed on February 8, 2019)

Sætre, T. P., \& Willars, G. (2002). The IFLA/UNESCO school library guidelines. The Hague: IFLA Headquaters.

Schultz-Jones, Barbara. \& Oberg, Dianne (Eds). (2015). Global action on school library guidelines. Berlin; Boston : De Gruyter Saur.

Poduzetništvo. (n.d.). Retrieved February 9, 2019 from https://hr.wikipedia.org/wiki/Poduzetni\%C5\%A1tvo.

Šutalo, V. (2019). Poduzetničke kompetencije i suradničko poduzetništvo: put do promjena i unaprjeđenja kvalitete programa i obrazovanja. Učenje za poduzetništvo, Vol 2(2). 161-164. 